\title{
Structural diversity in the first metal complexes of 2,5- dicarboxamidopyrroles and 2,5-dicarbothioamidopyrroles
}

\author{
Gareth W. Bates, ${ }^{a}$ Philip A. Gale, ${ }^{*, a}$ Mark E. Lighta, Mark I. Ogden ${ }^{*, b}$ and Colin N. Warriner. ${ }^{a}$ \\ Received (in XXX, XXX) 1st January 2007, Accepted 1st January 2007 \\ ${ }_{5}$ First published on the web 1st January 2007 \\ DOI: $10.1039 / \mathbf{b 0 0 0 0 0 0 x}$
}

Metal complexes of 2,5-dicarboxamidopyrroles and 2,5-dicarbothioamidopyrroles have been structurally characterised for the first time, complementing the significant amount of work that has been reported for the analogous pyridine ligands. $N, N^{\prime}$-Bis(3,5-dinitrophenyl)-3,4-diphenyl-1H10 pyrrole-2,5-dicarboxamide forms octahedral bis(tridentate) complexes with cobalt(III) and nickel(II), where the ligands are bound to the metal centres through deprotonated pyrrole and amide $\mathrm{N}$ atoms. $N, N$ '-Dibutyl-3,4-diphenyl-1 $H$-pyrrole-2,5-dicarboxthioamide and $N, N$ '-diphenyl3,4-diphenyl-1 $H$-pyrrole-2,5-dicarboxthioamide also form bis(tridentate) cobalt complexes but are only deprotonated at the pyrrole $\mathrm{N}$ atom, the remainder of the coordination sphere comprising the

15 thioamide $\mathrm{S}$ atoms. The dibutyl derivative was isolated as a Co(II) complex, whereas the diphenyl system deposited a Co(III) complex. In contrast, $N, N$ '-dibutyl-3,4-dichloro- $1 H$-pyrrole-2,5dicarboxamide was found to act as a bidentate ligand, in an octahedral cobalt(II) complex comprising of two bidentate pyrrole ligands, and two aqua ligands. Synthesis of $N, N$-bis(pyridin-2ylmethyl)-3,4-diphenyl-1 $H$-pyrrole-2,5-carboxamide gave a pyrrole ligand with increased 20 denticity. Reaction with cobalt(II) chloride resulted in the isolation of a dinuclear helicate complex. The ligand was found to have undergone addition of a methoxy group to one of the linking methylene carbons, presumably as a result of the oxidative addition of solvent methanol.

\section{Introduction}

Metal complexes of ligands containing pyridine-2,6${ }_{25}$ dicarboxamide groups have been investigated as models for enzyme active sites, as therapeutic agents, and as fundamentally interesting ligand systems with quite extensive structural diversity. ${ }^{1-4}$ The level of activity is such that over 150 structures involving a pyridine-2,6-dicarboxamide moiety 30 directly bound to a metal atom can be found on the Cambridge Crystallographic Database. ${ }^{5}$ In addition, these ligands have been shown to bind anions ${ }^{6-9}$ and neutral species. ${ }^{10,11}$ In terms of anion binding, the analogous pyrrole-2,5-dicarboxamides have been intensively studied, and found to be very effective 35 receptors. ${ }^{12-14}$ Under basic conditions, pyrrole-2,5dicarboxamides functionalised with electron withdrawing groups can undergo deprotonation at the pyrrole nitrogen upon addition of a basic anion. ${ }^{15-17}$ It thus seemed probable to us that such systems would be viable ligands for transition metal 40 cations. Remarkably, no such complexes have been structurally characterised to date. In this paper, we report the synthesis and structural characterisation of cobalt and nickel complexes of pyrrole dicarboxamides and dicarbothioamides 1-5. This series of ligands illustrates the great structural ${ }_{45}$ diversity possible in this new class of transition metal complex.<smiles>CCCCNC(=O)c1[nH]c(C(=O)NCCCC)c(-c2[nH]c(C(=O)Nc3cc([N+](=O)[O-])cc([N+](=O)[O-])c3)c(C(=O)Nc3cc([N+](=O)[O-])cc([N+](=O)[O-])c3)c2-c2ccccc2)c1Cl</smiles><smiles>CCCCNC(=S)c1[nH]c(C(=S)NCCCC)c(-c2ccccc2)c1-c1ccccc1</smiles><smiles>O=C(NCc1ccccn1)c1[nH]c(C(=O)NCc2ccccn2)c(-c2ccccc2)c1-c1ccccc1</smiles> 


\section{Experimental}

$N, N$ '-Bis(3,5-dinitrophenyl)-3,4-diphenyl-1 $H$-pyrrole-2,5dicarboxamide 1, ${ }^{17} \mathrm{~N}, \mathrm{~N}^{\prime}$-dibutyl-3,4-dichloro- $1 \mathrm{H}$-pyrrole-2,5dicarboxamide $2,{ }^{15}$ were synthesised according to literature 5 methods.

\section{Compound $3 \quad N 2, N 5,3,4$-tetraphenyl-1 $H$-pyrrole-2,5- bis(carbothioamide)}

$N 2, N 5,3,4$-tetraphenyl-1H-pyrrole-2,5-dicarboxamide ${ }^{12}$ (1.0g, $2.4 \mathrm{mmol})$ was suspended in THF $(100 \mathrm{~mL})$ and Lawesson's reagent ${ }^{18}(2.52 \mathrm{~g}, 6.24 \mathrm{mmol})$ added. The reaction was heated at reflux for 24 hours and then allowed to cool and the solvent 15 removed in vacuo. The residue was purified by column chromatography on silica gel eluting with dichloromethane $/ 5 \%$ hexane which affording the product as a yellow powder. The powder was recrystallised from dichloromethane/acetonitrile $1: 1 \mathrm{v} / \mathrm{v}$ affording the product as ${ }_{20}$ pale yellow crystals $(0.66 \mathrm{~g}, 58 \%$ yield $)$.

${ }^{1} \mathrm{H}$ NMR (400 MHz, $\mathrm{CDCl}_{3}$ ) $\delta(\mathrm{ppm}): 7.17$ (t, 2H, ArH), 7.26 (m, 4H, ArH), $7.40(\mathrm{~m}, 12 \mathrm{H}, \mathrm{ArH}), 8.87(\mathrm{~s}, 2 \mathrm{H}, \mathrm{NH}), 11.14(\mathrm{~s}$, $1 \mathrm{H}, \mathrm{NH})$.

${ }^{13} \mathrm{C}\left\{{ }^{1} \mathrm{H}\right\}$ NMR $\left(100 \mathrm{MHz} \quad \mathrm{CDCl}_{3}\right) \delta: 122.1,123.8,126.3$, $25128.8,128.8,129.4,131.0,131.1,132.6,138.4,182.6$.

HRMS ES $\left(\mathrm{M}+\mathrm{Na}^{+}\right)$: calc: 512.1225 found: 512.1209

Microanalysis for $\mathrm{C}_{30} \mathrm{H}_{23} \mathrm{~N}_{3} \mathrm{~S}_{2} \cdot \mathrm{MeCN}$. Calc. (\%) $\mathrm{C}=72.42, \mathrm{H}$ $=4.94, \mathrm{~N}=10.56$. Found (\%) $\mathrm{C}=72.37, \mathrm{H}=4.84, \mathrm{~N}=10.22$. (MeCN observed in ${ }^{1} \mathrm{H}$ NMR) $\mathrm{Mp}: 233-234^{\circ} \mathrm{C}$

30

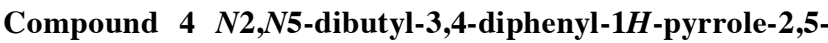
bis(carbothioamide)

$N 2, N 5$-dibutyl-3,4-diphenyl-1 $H$-pyrrole-2,5-dicarboxamide ${ }^{12}$ $35(1.05 \mathrm{~g}, 2.3 \mathrm{mmol})$ was suspended in THF $(100 \mathrm{~mL})$ and Lawesson's reagent ${ }^{18}(2.52 \mathrm{~g}, 6.24 \mathrm{mmol})$ added. The reaction was heated at reflux for 24 hours and then allowed to cool and the solvent removed in vacuo. The residue was purified by column chromatography on silica gel eluting with 40 dichloromethane and then recrystallised from dichloromethane solution affording the product as pale yellow crystals $(0.68 \mathrm{~g}, 63 \%$ yield $)$.

${ }^{1} \mathrm{H}$ NMR (400 MHz, $\left.\mathrm{CDCl}_{3}\right) \delta(\mathrm{ppm}): 0.73\left(\mathrm{t},, 6 \mathrm{H}, \mathrm{CH}_{3}\right), 0.95$ $\left(\mathrm{m}, 4 \mathrm{H}, \mathrm{CH}_{2} \mathrm{CH}_{3}\right), 1.18\left(\mathrm{~m}, 4 \mathrm{H}, \mathrm{CH}_{2}\right), 3.49\left(\mathrm{~m}, 4 \mathrm{H}, \mathrm{NCH}_{2}\right)$, ${ }_{45} 7.08(\mathrm{~s}, 2 \mathrm{H}$, amide $\mathrm{NH}), 7.18(\mathrm{~m}, 4 \mathrm{H}, \mathrm{Ar}), 7.28(\mathrm{~m}, 6 \mathrm{H}, \mathrm{Ar})$, 10.94 (s, 1H, NH).

${ }^{13} \mathrm{C}\left\{{ }^{1} \mathrm{H}\right\}$ NMR $\left(100 \mathrm{MHz}\right.$ DMSO- $\left.d_{6}\right) \delta: 13.6,19.9,29.8,45.4$, $123.7,128.3,129.1,129.2,130.6,132.9,185.2$

HRMS ES${ }^{+}\left(\mathrm{M}+\mathrm{Na}^{+}\right)$: calc: 472.1851 found: 472.1839 .

50 Microanalysis for $\mathrm{C}_{26} \mathrm{H}_{31} \mathrm{~N}_{3} \mathrm{~S}_{2}$ Calc. (\%) $\mathrm{C}=69.45, \mathrm{H}=6.95$, $\mathrm{N}=9.34$. Found (\%) $\mathrm{C}=69.29, \mathrm{H}=6.94, \mathrm{~N}=9.22$; Mp: $214-$ $215^{\circ} \mathrm{C}$

Compound $5 \mathrm{~N}, \mathrm{~N}$-Bis(pyridin-2-ylmethyl)-3.4-diphenyl${ }_{55} \mathbf{1 H}$-pyrrole-2,5-carboxamide

3,4-Diphenyl-1H-pyrrole-2,5-dicarboxylic acid ${ }^{19,} 20$ (1.80 g; $5.9 \mathrm{mmol})$ was refluxed in thionylchloride $(40 \mathrm{~mL})$ for 3 hours. The reaction mixture was cooled and reduced in vacuo and the resultant solid was dissolved in dichloromethane (50 $60 \mathrm{~mL}$ ). This was then added dropwise to a stirring solution of 2-(aminomethyl)pyridine $(1.30 \mathrm{~g} ; 12 \mathrm{mmol})$, triethylamine (2 $\mathrm{mL})$ in dichloromethane $(50 \mathrm{~mL})$ with a catalytic amount of DMAP. The reaction mixture was stirred for 48 hours. Water $(100 \mathrm{~mL})$ was added and the organic layer was separated, ${ }_{65}$ dried with $\mathrm{MgSO}_{4}$, filtered and reduced in vacuo. The product was the recrystallised from acetonitrile to give the product as a pale yellow crystalline powder in a yield $=63 \% ; 1.82 \mathrm{~g} ; 3.7$ mmol.

${ }^{1} \mathrm{H}$ NMR (400 MHz, DMSO- $\left.d_{6}\right) \delta(\mathrm{ppm}): 4.45(\mathrm{~d}, 4 \mathrm{H}, J=5 \mathrm{~Hz}$, $\left.{ }_{70} \mathrm{CH}_{2}\right)$, 7.10-7.20 (m, 4H, Ar-H), 7.21-7.25 (m, 10H, Ar-H), $7.71(\mathrm{dt}, 2 \mathrm{H}, J=7.5 \mathrm{~Hz}, 1.5 \mathrm{~Hz}, \mathrm{Ar}-\mathrm{H}), 7.89(\mathrm{t}, 2 \mathrm{H}, J=5.5 \mathrm{~Hz}$, Ar-H), 8.38-8.41 (m, 2H, Amide-NH), 12.05 (s, 1H, pyrrole$\mathrm{NH}) ;{ }^{13} \mathrm{C}\left\{{ }^{1} \mathrm{H}\right\}$ NMR $\left(100 \mathrm{MHz}\right.$ DMSO- $\left.d_{6}\right) \delta: 45.2\left(\mathrm{CH}_{2}\right)$, 122.3 (Ar-CH), 123.2 (Ar-CH), 125.1, 127.8 (Ar-CH), 128.2, 75128.8 (Ar-CH), 131.8 (Ar-CH), 134.9, 137.8 (Ar-CH), 149.7 $(\mathrm{Ar}-\mathrm{CH}), 158.4,161.2$; IR $v \mathrm{~cm}^{-1} 3388 \mathrm{~s}, 3237 \mathrm{~s}, 3053 \mathrm{~s}, 3029 \mathrm{~s}$, $1644 \mathrm{~s}, 1556 \mathrm{~s}, 1535 \mathrm{~s} 1303 \mathrm{~s}, 1261 \mathrm{~s} ;$ LRMS $\mathrm{ES}^{+}: 488.5$ $(\mathrm{M}+\mathrm{H})^{+}, 975.9(2 \mathrm{M}+\mathrm{H})^{+}$; Microanalysis for $\mathrm{C}_{30} \mathrm{H}_{25} \mathrm{~N}_{5} \mathrm{O}_{2}$. Calc. $(\%) \mathrm{C}=73.90, \mathrm{H}=5.17, \mathrm{~N}=14.36$. Found (\%) $\mathrm{C}=$ ${ }_{80} 74.11, \mathrm{H}=5.22, \mathrm{~N}=14.34$; $\mathrm{Mp}: 181-183^{\circ} \mathrm{C}$

\section{Nickel complex of compound 1}

$N, N$ '-Bis(3,5-dinitrophenyl)-3,4-diphenyl-1 $H$-pyrrole-2,5dicarboxamide $1(50 \mathrm{mg}, 0.08 \mathrm{mmol}$ ), nickel(II) chloride hexahydrate $(10 \mathrm{mg}, 0.04 \mathrm{mmol})$, and potassium hydroxide $85(15 \mathrm{mg}, 0.27 \mathrm{mmol})$ were suspended in methanol $(30 \mathrm{~mL})$ and stirred at room temperature for $24 \mathrm{~h}$. Diffusion of ether into the resulting dark yellow-brown solution resulted in deposition of fine yellow powder mixed with a small number of dark brown needle-like crystals. Yield, $5 \%$.

\section{${ }_{90}$ Cobalt complex of compound 1}

$N, N$ '-Bis(3,5-dinitrophenyl)-3,4-diphenyl-1 $H$-pyrrole-2,5dicarboxamide 1 (50 $\mathrm{mg}, 0.08 \mathrm{mmol}$ ), cobalt(II) chloride hexahydrate $(10 \mathrm{mg}, 0.04 \mathrm{mmol})$, and potassium hydroxide (9 $\mathrm{mg}, 0.16 \mathrm{mmol})$ were suspended in methanol $(30 \mathrm{~mL})$ and 95 stirred at room temperature for $24 \mathrm{~h}$. Diffusion of ether into the resulting dark red-brown solution resulted in the deposition of dark brown needles. Yield, $60 \%$.

\section{Cobalt complex of compound 2}

$N, N$ '-Dibutyl-3,4-dichloro-1 $H$-pyrrole-2,5-dicarboxamide $\quad 2$ $100(28 \mathrm{mg}, 0.08 \mathrm{mmol})$, cobalt(II) chloride hexahydrate $(10 \mathrm{mg}$, $0.04 \mathrm{mmol}$ ), and excess sodium hydride were suspended in dimethylformamide $(30 \mathrm{~mL})$ and stirred at room temperature for $24 \mathrm{~h}$. A black microcrystalline powder was deposited. Upon prolonged standing, exposed to the atmosphere, a small 105 number of pink tablets, appropriate for single crystal structure determination, crystallised from the mixture. Yield, 5\%

\section{Cobalt complexes of compounds 3 and 4}

$N, N$ '-Dibutyl-3,4-diphenyl-1 $H$-pyrrole-2,5-dicarboxthioamide 4 (38 mg, $0.08 \mathrm{mmol})$, cobalt(II) chloride hexahydrate $(10 \mathrm{mg}$, $1100.04 \mathrm{mmol})$, and potassium hydroxide $(9 \mathrm{mg}, 0.16 \mathrm{mmol})$ were suspended in methanol $(30 \mathrm{~mL})$ and stirred at room temperature for $24 \mathrm{~h}$. The resulting brown powder was allowed to settle, and the methanol solvent was decanted. 
Acetonitrile $(20 \mathrm{~mL})$ was added to dissolve the majority of the precipitate. After filtration, the solvent was allowed to evaporate slowly, depositing deep red prisms appropriate for single crystal structure determination, along with some 5 amorphous material. Yield, 30\%To obtain the complex of compound 3 the same procedure was followed using $N, N$ 'diphenyl-3,4-diphenyl-1 $H$-pyrrole-2,5-dicarboxthioamide 3 . Yield, $40 \%$.

\section{${ }_{10}$ Cobalt complex of compound 5}

$\mathrm{N}, \mathrm{N}$-Bis(pyridin-2-ylmethyl)-3.4-diphenyl-1 $H$-pyrrole-2,5carboxamide 5 (50 mg, $0.10 \mathrm{mmol})$ and cobalt(II) chloride hexahydrate $(24 \mathrm{mg}, 0.10 \mathrm{mmol})$, and potassium hydroxide $(17 \mathrm{mg}, 0.30 \mathrm{mmol})$ were suspended in methanol $(30 \mathrm{~mL})$ and 15 stirred at room temperature for $24 \mathrm{~h}$. Small dark green needles were deposited from the solution. These dissolved upon addition of dichloromethane $(10 \mathrm{~mL})$. Upon slow evaporation of the solvent, dark green needles appropriate for single crystal structure determination were deposited, along with 20 some amorphous material. Yield, $20 \%$.

\section{Results and Discussion}

\section{Synthesis}

Thioamides were prepared according to literature procedures 25 by treating the corresponding amide ${ }^{12}$ with Lawesson's reagent ${ }^{18}$ at reflux in THF. Analogous pyrrole thioamides that do not contain phenyl substituents in the 3- and 4-positions of the pyrrole ring have been prepared by Jurczak. ${ }^{21}$ Compound 5 was prepared by preparation of the pyrrole bis-acid chloride 30 and subsequent coupling with 2-(aminomethyl)pyridine.

The syntheses of the complexes were generally achieved following a modification of the procedure reported by Grossel for analogous pyridine amides. ${ }^{22}$ The appropriate metal(II) chloride and ligand were slurried in methanol, followed by the 35 addition of a slight excess of potassium hydroxide. Addition of the base induced dissolution of the ligand and intensely coloured solutions were formed. Crystals appropriate for single crystal structure determinations were obtained by slow evaporation of the solvent, or diffusion of ether into the 40 solution. The crystals were deposited along with amorphous material that complicated attempts to obtain accurate microanalytical data.

An exception to this procedure was the cobalt complex of ligand 2. In methanol solution the intensity of the colour 45 formed upon addition of base faded over time, possibly due to hydrolysis of the complex. Using sodium hydride as the base and $\mathrm{dmf}$ as the solvent produced a black precipitate immediately. Upon prolonged standing in ambient conditions a small number of pink crystal deposited from the mixture 50 which were appropriate for structural characterisation.

While additional work is required to optimise the synthesis of the amidopyrrole complexes, the work carried out here is sufficient to allow investigation of the coordination modes of these ligands for the first time.

${ }_{55}$ Complexes of dicarboxamidopyrrole 1
Ligand 1 was selected for initial investigations as the electron withdrawing dinitrophenyl groups would enhance the acidity of the amide and pyrrole protons, and it was anticipated this would facilitate isolation of the metal complexes. A 60 nickel(II) $\$$ and a cobalt(III) 9 complex were successfully crystallised as dark brown prisms, and the structures elucidated. The nickel complex can be formulated as $\mathrm{K}_{4}[\mathrm{Ni}(\mathbf{1}-$ $\left.3 \mathrm{H})_{2}\right]\left(\mathrm{CH}_{3} \mathrm{OH}\right)_{6}\left(\mathrm{H}_{2} \mathrm{O}\right)$, (Figures 1 and 2) and the cobalt complex as $\mathrm{K}_{3}\left[\mathrm{Co}(1-3 \mathrm{H})_{2}\right]\left(\mathrm{CH}_{3} \mathrm{OH}\right)_{3}\left(\mathrm{H}_{2} \mathrm{O}\right)_{2}$ (Figure 3). The

${ }_{65}$ pyrrole and amide $\mathrm{N}$ atoms are deprotonated so that each ligand is a trianion. Both complex anions are bis-tridentate complexes (Figures 1 and 2), the two orthogonal ligands resulting in a distorted octahedral coordination environment about the metal centres. Similar coordination complexes have 70 been reported for pyridine-2,6-dicarboxamide ligands, for both cobalt(III) $)^{22-24}$ and nickel(II). ${ }^{2,25}$

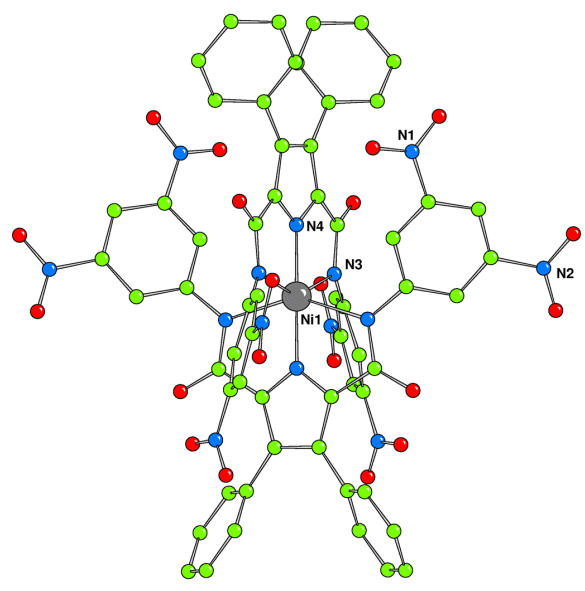

Figure 1 The nickel complex $\mathrm{Ni1}_{2}{ }^{4-}$. Counter cations, solvent molecules and hydrogen atoms have been omitted for clarity.

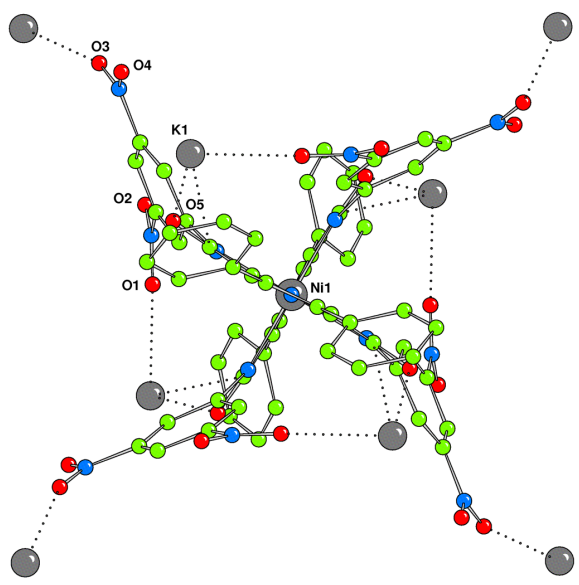

Figure 2 Part of the 3D network in the nickel complex of compound 1 formed via coordination through the potassium counter cations, viewed down the $c$ axis. The potassium is coordinated to 6 oxygens; 2 from separate $\mathrm{NO}_{2}$ groups, 2 from methanols, 1 carbonyl and a water. 


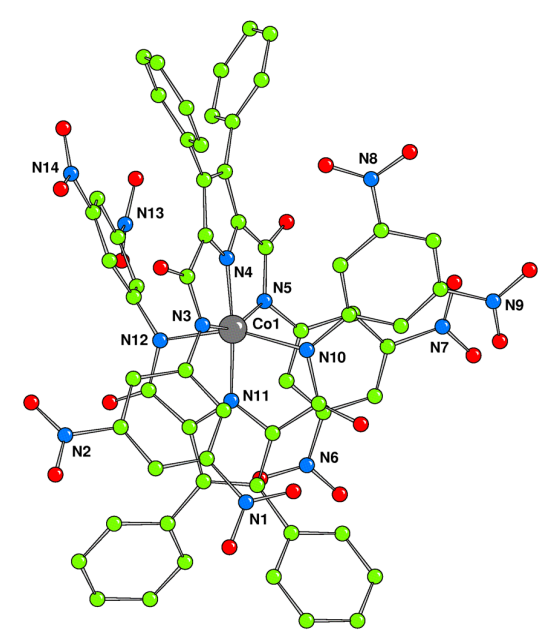

Figure 3 The X-ray crystal structure of the cobalt complex $\mathrm{Co} 1_{2}{ }^{3-}$. Counter cations, solvent molecules and hydrogen atoms have been omitted for clarity.

Both structures form complex 3D networks through coordination of the potassium ions to the nitro and carbonyl groups. The $\mathrm{K}$ coordination number varies from 6-9 and is completed via a $\pi$ interaction to a phenyl ring and solvent 10 water and methanol. ${ }^{23}$.

\section{Complex of dicarboxamidopyrrole 2}

The chloro-substituted pyrrole $\mathbf{2}$ was introduced as an example of a ligand where the acidity of the $\mathrm{NH}$ protons is increased through the introduction of electron-withdrawing 15 groups on the pyrrole ring rather than on the amide groups. The amide butyl substituents will not tend to stabilise the deprotonated amide $\mathrm{N}$ atoms, and thus it was anticipated that the ligand may only deprotonate readily at the pyrrole $\mathrm{N}$ atom, under the crystallisation conditions used. The synthesis

20 proved to be problematic, with the only crystalline product resulting from what is presumed to be a slow hydrolysis of the product initially formed in $\mathrm{dmf}$ solvent in the presence of sodium hydride. The pink tablets that slowly deposited were suitable for structure determination, the results of which are ${ }_{25}$ consistent with the formulation $\left[\mathrm{Co}(2-\mathrm{H})_{2}\left(\mathrm{OH}_{2}\right)_{2}\right] \cdot \gamma \quad \mathrm{As}$ expected, the pyrrole ligand is deprotonated once only, at the pyrrole $\mathrm{N}$ atom. Each ligand is bidentate only, bound through the pyrrole $\mathrm{N}$ atom and one of the amide $\mathrm{O}$ atoms (Figure 4). The remaining two sites in the octahedral coordination sphere 30 are occupied by the two water molecules. Relating this structure once again to analogous pyridine-based ligands, a comparable structure is found in two cobalt(II) complexes of $N, N, N$ ', $N$ '-tetraethylpyridine-2,6-dicarboxamide (deap). ${ }^{26}$ The compounds $\left[\mathrm{Co}(\text { deap })_{2}\left(\mathrm{H}_{2} \mathrm{O}\right)_{2}\right](X)_{2}$, where $X=\mathrm{PF}_{6}{ }^{-}$and $\mathrm{ClO}_{4}{ }^{-}$, 35 exhibit a very similar coordination complex structure, but here the bidentate ligands are neutral and the charge is offset by the counteranions. A key difference between the pyridine and pyrrole complexes is that while the pyrrole $\mathrm{N}$ atoms are trans, the pyridine $\mathrm{N}$ atoms are cis. Once again, the charge on the 40 pyrrole ring is a probable explanation for this difference. While both the pyridine and pyrrole complexes are connected by a network of hydrogen bonds, the details differ because of this difference in coordination geometries. The water molecules form hydrogen bonds to adjacent complexes 45 resulting in chain formation in the solid state (Figure 5).

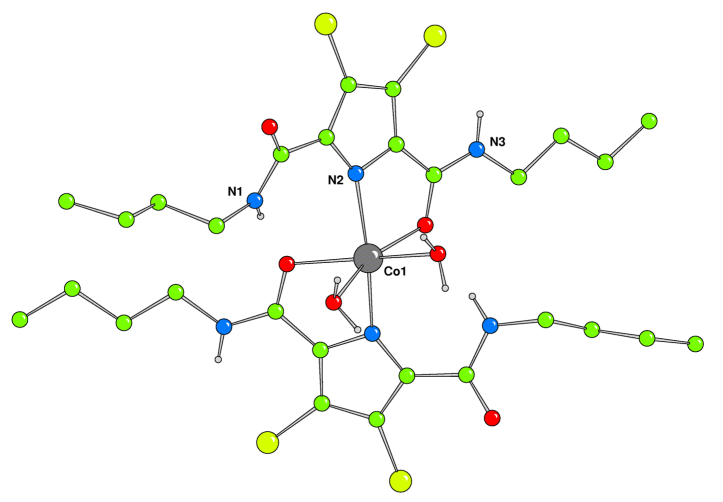

Figure 4 Cobalt complex of cobalt complex of receptor 2.

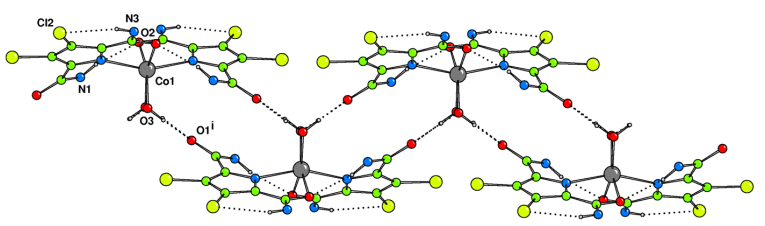

50 Figure 5 Hydrogen bonded chains extend in the [101] direction, butyl groups omitted for clarity, (i) $-\mathrm{x}+1, \mathrm{y},-\mathrm{z}+1 / 2$.

\section{Complexes of dicarbothioamidopyrroles 3 and 4}

The thioamide ligands 3 and $\mathbf{4}$ were treated with cobalt(II) 55 chloride under comparable reaction conditions to those used for $\mathbf{1}$. The deep red prisms isolated were suitable for structural characterisation, and the results are consistent with the formulations $\left[\mathrm{Co}^{\mathrm{II}}(3-\mathrm{H})_{2}\right] \beta$ and $\left[\mathrm{Co}^{\mathrm{III}}(4-\mathrm{H})_{2}\right]\left(\mathrm{Co}^{\mathrm{III}} \mathrm{Cl}_{4}\right)$. $\S$ Both structures are free of solvent in the crystal lattice. As found in 60 the complex of $\mathbf{2}$, the thioamide ligands are only singly deprotonated, at the pyrrole $\mathrm{N}$ atom. In this case, however, the pyrrole ligands once again form octahedral bis(tridentate) complexes about the cobalt atoms (Figure 6,7), with both amide moieties coordinated through the $\mathrm{S}$ atoms. The complex 65 of $\mathbf{3}$ is assumed to be a cobalt(II) complex based on charge balance considerations, whereas the complex of $\mathbf{4}$ is presumably a cobalt(III) complex, with the charge balanced by the $\mathrm{Co}^{\mathrm{III}} \mathrm{Cl}_{4}^{-}$counteranion. Cobalt complexes of the dicarbothioamidopyridine ligands are known, but in all cases 70 the cobalt is coordinated to only one ligand, with the remainder of the coordination sphere comprising of anions, such as halides or thiocyanate. ${ }^{27}$ This may be due to subtle differences in the pyrrole and pyridine ligand geometries, or may be associated with the negative charge on the pyrrole 75 ligand. The latter hypothesis is supported by the structure of the cobalt(III) complex of pyridine-2,6bis(monothiocarboxylate), which has a comparable bis(tridentate) coordination sphere albeit as a complex anion. ${ }^{28}$ The average Co-N bond distance in 4 is $1.873(8) \AA$ 80 compared to that of $1.913(7) \AA$ for the cobalt(III) complex of 
pyridine-2,6-bis(monothiocarboxylate), and the average Co-S

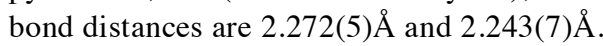

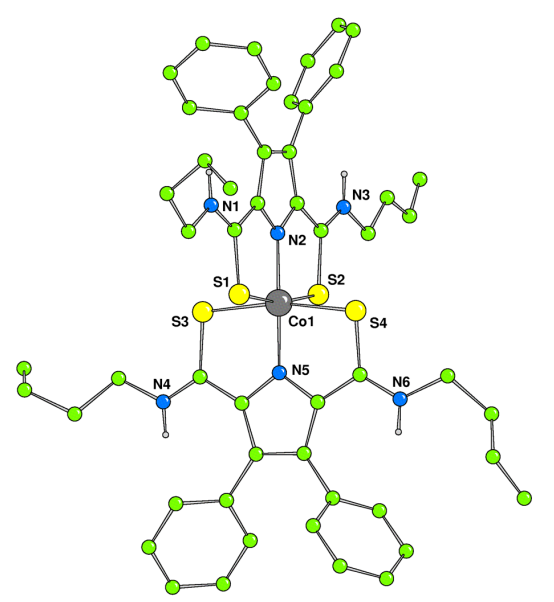

5 Figure 6 The X-ray crystal structure of the cobalt (II) complex of receptor 3.

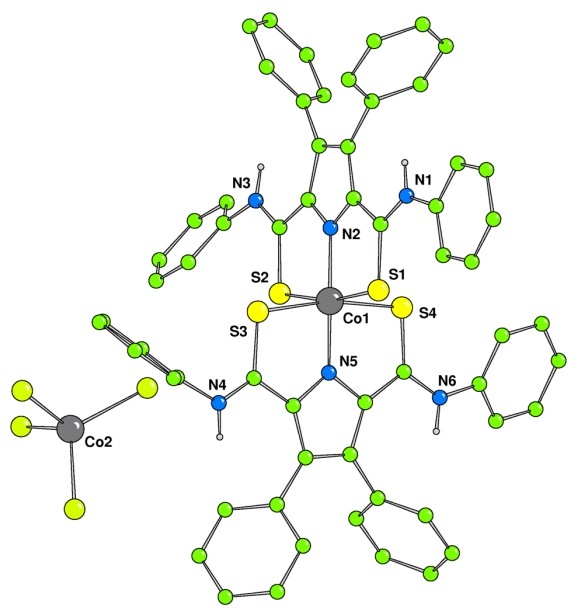

Figure 7 The X-ray crystal structure of the cobalt (III) complex of receptor 4 .

The difference in cobalt oxidation states in the isolated complexes of $\mathbf{3}$ and $\mathbf{4}$ is intriguing. It is possible that this is a result of differences in solubilities or subtle changes in the 15 reaction conditions. It is also plausible that the phenyl amide substituents on $\mathbf{4}$ allow greater delocalisation of the metal cation charge, stabilising the higher oxidation state, in comparison to the alkyl substituents of ligand 3. Further work is required to confirm this hypothesis, but the isolation of a 20 cobalt(II) and a cobalt(III) complex with very similar coordination spheres and geometries suggests that subtle control of oxidation state in these systems will be possible.

\section{Complex of pyridine-functionalised dicarboxamidopyrrole 5}

${ }_{25}$ Ligands 1-4 are potentially tridentate ligands. Adding additional donor atoms to the amide substituents expands the denticity of these systems, as illustrated by the pyridinefunctionalised ligand $\mathbf{5}$. Such pentadentate ligands can form complexes of greater structural diversity, including ${ }_{30}$ polynuclear helicate complexes. ${ }^{29}$ Reaction of the pyrrolediacid chloride with 2-(aminomethyl)pyridine afforded the bis pyridine pentadentate ligand $\mathbf{5}$ that was structurally characterised after crystallisation from acetonitrile (Figure 8). $\delta$

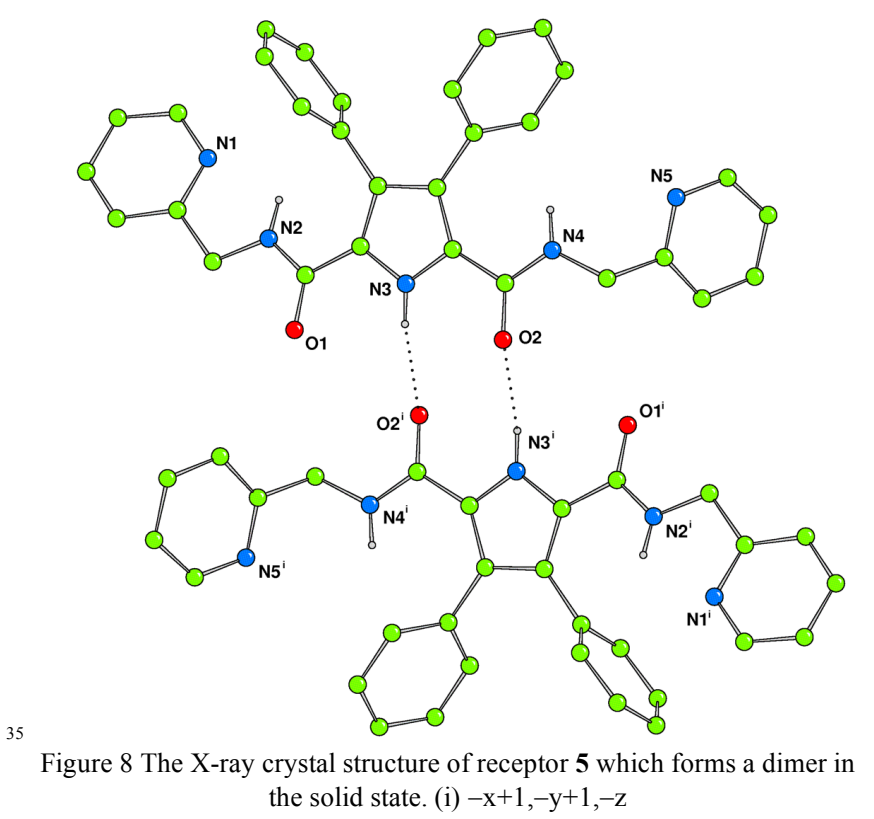

The diphenyl pyrrole can be compared to the unsubstituted 40 pyridine analogue in that they both form hydrogen bonded dimers. However, the conformation of the molecules and the supramolecular assemblies are very different. In the case of the pyrrole the geometry adopted is more open with the angles between the substituent pyridine rings and the central pyrrole 45 being $23.43(4)^{\circ}$ and $56.49(6){ }^{\circ}$ compared to $63.62(6)^{\circ}$ and $78.86\left(5^{\circ}\right)$ with the latter case also being more symmetrical. The amide groups are anti relative to the pyrrole $\mathrm{NH}$ and this has the effect of twisting both phenyls into a position favouring $\pi \cdots \mathrm{H}-\mathrm{N}$ interactions and allowing a simple bi $\mathrm{N}$ ${ }_{50} \mathrm{H} \cdots \mathrm{O}$ centrosymmetric hydrogen bonded dimer to form. In the case of the pyridine the molecule adopts a conformation leading to a cleft being formed as the amides are syn relative to the pyridine nitrogen. This encourages hydrogen bond formation between the substituent pyridines into the cleft to 55 form a dimer with a 2 -fold rotation axis. ${ }^{30}$ The pyridine analogue of $\mathbf{5}$ has been reported to form mononuclear, ${ }^{2,22,31}$ dinuclear $^{2}, 32$ and tetranuclear ${ }^{2}$ complexes. It is notable that the mononuclear complexes are formed with iron(III) and cobalt(III), whereas the polynuclear complexes are isolated as 60 metal(II) complexes. Reaction of 5 with cobalt(II) chloride in the presence of base resulted in the deposition of dark green needles, which were of sufficient quality for a structure determination. The results are consistent with the formation of a dinuclear helicate structure, where the ligands are fully ${ }_{65}$ deprotonated, indicating that a cobalt(III) helicate has been isolated (Figure 9). $\varepsilon$ The crystallographic refinement provides 
unambiguous proof of formation of a helicate Co(III) structure. However, there exist additional electron density peaks on the periphery of the molecule that can be best modelled as a partially substituted methoxy group. Similar 5 reactivity has been observed previously in related systems, where a $\mathrm{C}-\mathrm{H}$ bond $\alpha$ to coordinated amidate has been oxidised. ${ }^{33,34}$ The methoxy-substituted ligand was proposed to be formed as a result of the attack of solvent methanol upon an intermediate imine ${ }^{34}$ and a comparable mechanism is 10 consistent with the observations made here.

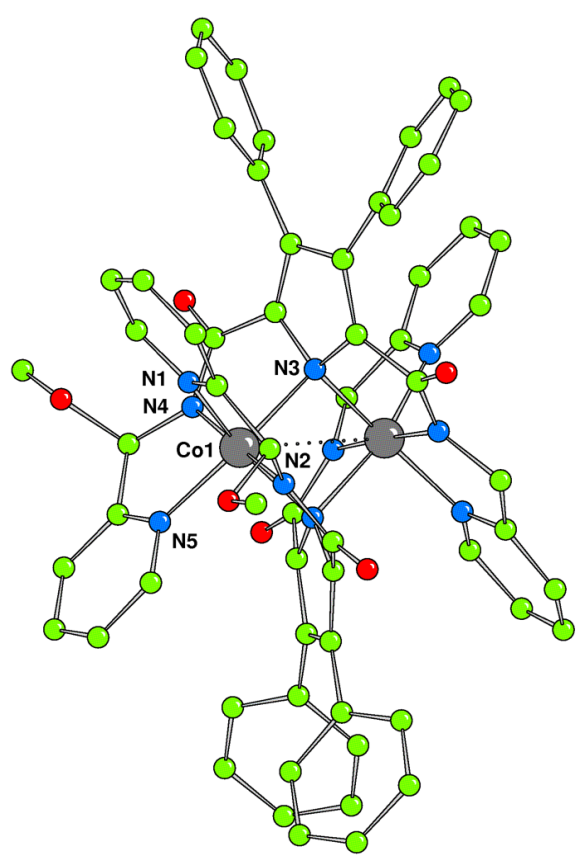

Figure 9 The helical cobalt(III) complex formed by the reaction of cobalt(II) with receptor 5

\section{${ }_{15}$ Conclusions}

The first structural studies of metal complexes of 2,5dicarboxamidopyrroles and 2,5-dicarbothioamidopyrroles have shown that many features of the analogous and widely studied pyridine-based systems are accessible in these pyrrole

20 ligands. The acidic proton on the pyrrole mioety provides an additional negative charge which results in subtle variations in the structural chemistry when compared to the pyridine analogues. Changes in the amide substituent appears to result in changes in the relative stabilities of the oxidation state of 25 the metal centre, at least for cobalt, and further work is underway to explore these effects in more detail.

\section{Notes and references}

${ }^{a}$ School of Chemistry, University of Southampton, Southampton, SO17 IBJ, UK. Fax: 44 2380596805; Tel: 4423 80593332; E-mail: 30 philip.gale@soton.ac.uk

${ }^{b}$ Nanochemistry Research Institute, Department of Applied Chemistry, Curtin University of Technology, Perth, Australia, . Fax: 6189266 4699; Tel: 6189266 2483; E-mail: m.ogden@curtin.edu.au $\dagger$ Electronic Supplementary Information (ESI) available: 35 [Characterisation data for compounds 3-5 and CIF files]. See DOI: $10.1039 / \mathrm{b} 000000 \mathrm{x} /$

$\ddagger$ Crystal data for 1-Ni $\mathrm{C}_{66} \mathrm{H}_{58} \mathrm{~K}_{4} \mathrm{~N}_{14} \mathrm{NiO}_{27}, \mathrm{Mr}=1694.37, \mathrm{~T}=120(2) \mathrm{K}$, tetragonal, space group $P 4_{2} / n, a=15.602(1), c=15.9970(6) \AA, V=$ $403894.0(4) \AA^{3}, \rho_{\text {calc }}=1.445 \mathrm{~g} \mathrm{~cm}^{-3}, \mu=0.550 \mathrm{~mm}^{-1}, Z=2$, reflections collected: 16842, independent reflections: $4460\left(R_{\text {int }}=0.0995\right)$, final $R$ indices $[I>2 \sigma I]: R 1=0.0797, w R 2=0.2010, R$ indices (all data): $R 1=$ 0.1374 . $w R 2=0.2307$. One of the solvent molecules is disordered over 2 sites, and a partially occupied water is present. This data was collected on 45 a Bruker Nonius KappaCCD with a Mo rotating anode generator; standard data collection and processing procedures were followed.

- Crystal data for 1-Co $\mathrm{C}_{63} \mathrm{H}_{48} \mathrm{CoK}_{3} \mathrm{~N}_{14} \mathrm{O}_{25}, \mathrm{Mr}=1577.38, \mathrm{~T}=$ $120(2) \mathrm{K}$, monoclinic, space group $P 21 / n, a=14.6300(16), b=$ $5029.024(3), c=15.4370(17) \AA, \beta=95.507(2)^{\circ}, V=6524.6(12) \AA^{3}$, $\rho_{\text {calc }}=1.606 \mathrm{~g} \mathrm{~cm}^{-3}, \mu=0.552 \mathrm{~mm}^{-1}, \mathrm{Z}=4$, reflections collected: 48591, independent reflections: $11503\left(R_{\mathrm{int}}=0.0888\right)$, final $R$ indices $[I>2 \sigma I]: R 1=0.0866, w R 2=0.2436, R$ indices (all data): $R 1=$ 0.1330 . $w R 2=0.2854$. One of the solvent molecules is disordered 55 over 2 sites. This data was collected on a Bruker SMART APEX2 CCD diffractometer at the SRS station 9.8 at Daresbury. ${ }^{35,36}$

$\gamma$ Crystal data for 2-Co $\mathrm{C}_{28} \mathrm{H}_{44} \mathrm{Cl}_{4} \mathrm{CoN}_{6} \mathrm{O}_{6}, \mathrm{Mr}=761.42, \mathrm{~T}=120(2) \mathrm{K}$, monoclinic, space group $C 2 / c, a=15.3090(6), b=21.0300(14), c=$ 60 13.4079(6) $\AA, \beta=124.112(3)^{\circ}, V=3573.9(3) \AA^{3}, \rho_{\text {calc }}=1.415 \mathrm{~g} \mathrm{~cm}^{-3}, \mu$ $=0.826 \mathrm{~mm}^{-1}, \quad \mathrm{Z}=4$, reflections collected: 24246 , independent reflections: $4072\left(R_{\text {int }}=0.0633\right)$, final $R$ indices $[I>2 \sigma I]: R 1=0.0385$, $w R 2=0.0805, R$ indices (all data): $R 1=0.0689 . w R 2=0.0909$. This data was collected on a Bruker Nonius KappaCCD with a Mo rotating anode 65 generator; standard data collection and processing procedures were followed.

$\beta$ Crystal data for 3-Co $\mathrm{C}_{52} \mathrm{H}_{60} \mathrm{CoN}_{6} \mathrm{~S}_{4}, \mathrm{Mr}=956.23, \mathrm{~T}=120(2) \mathrm{K}$, triclinic, space group $P-1, a=11.820(5), b=12.819(5), c=17.669(5) \AA$, ${ }_{70} \alpha=111.096(5), \beta=100.723(5), \gamma=92.892(5)^{\circ}, V=2434.0(16) \AA^{3}, \rho_{\text {calc }}$ $=1.305 \mathrm{~g} \mathrm{~cm}^{-3}, \mu=0.566 \mathrm{~mm}^{-1}, \mathrm{Z}=2$, reflections collected: 39694 , independent reflections: $11133\left(R_{\text {int }}=0.0905\right)$, final $R$ indices $[I>2 \sigma I]$ : $R 1=0.0774, w R 2=0.1858, R$ indices (all data) $: R 1=0.1479 . w R 2=$ 0.2146 . Both butyl groups are disordered as is the rotation angle of one of 75 the phenyl groups. This data was collected on a Bruker Nonius KappaCCD with a Mo rotating anode generator; standard data collection and processing procedures were followed.

$\S$ Crystal data for 4-Co $\mathrm{C}_{60} \mathrm{H}_{44} \mathrm{Cl}_{4} \mathrm{Co}_{2} \mathrm{~N}_{6} \mathrm{~S}_{4}, \mathrm{Mr}=1236.91, \mathrm{~T}=120(2) \mathrm{K}$, 80 triclinic, space group $P-1, a=10.9056(12), b=15.0017(17), c=$ 20.544(2) $\AA, \alpha=70.153(6), \beta=77.191(6), \gamma=89.844(6)^{\circ}, V=3073.0(6)$ $\AA^{3}, \rho_{\text {calc }}=1.337 \mathrm{~g} \mathrm{~cm}^{-3}, \mu=0.891 \mathrm{~mm}^{-1}, \mathrm{Z}=2$, reflections collected 48354, independent reflections: $10811\left(R_{\mathrm{int}}=0.1411\right)$, final $R$ indices $[I>$ $2 \sigma \Gamma: R 1=0.1962, w R 2=0.4795, R$ indices (all data): $R 1=0.2665 . w R 2$ $85=0.5137$. Getting a good data set from these poorly diffracting crystals was not possible. The structure reported here was solved and refined from a data set containing ill defined reflections and diffuse scattering. This data was collected on a Bruker Nonius KappaCCD with a Mo rotating anode generator; standard data collection and processing procedures were 90 followed.

$\delta$ Crystal data for compound $5 \mathrm{C}_{30} \mathrm{H}_{25} \mathrm{~N}_{5} \mathrm{O}_{2}, \mathrm{Mr}=487.55, \mathrm{~T}=120(2) \mathrm{K}$, triclinic, space group $P-1, a=9.6907(3), b=10.9090(3), c=12.3922(3)$ $\AA, \alpha=87.119(2), \beta=67.8340(10), \gamma=77.531(2)^{\circ}, V=1183.91(6) \AA^{3}$, $95 \rho_{\text {calc }}=1.368 \mathrm{~g} \mathrm{~cm}^{-3}, \mu=0.088 \mathrm{~mm}^{-1}, \mathrm{Z}=2$, reflections collected: 22295 , independent reflections: $5409\left(R_{\text {int }}=0.0467\right)$, final $R$ indices $[I>2 \sigma I]: R 1$ $=0.0483, w R 2=0.1059, R$ indices (all data): $R 1=0.0627 . w R 2=0.1129$. This data was collected on a Bruker Nonius KappaCCD with a Mo rotating anode generator; standard data collection and processing 100 procedures were followed.

$\varepsilon$ Crystal data for $\mathbf{5}_{2}-\mathbf{C o}_{2} \quad \mathrm{C}_{62} \mathrm{H}_{48} \mathrm{Co}_{2} \mathrm{~N}_{10} \mathrm{O}_{6}, \mathrm{Mr}=1146.96, \mathrm{~T}=120(2) \mathrm{K}$, monoclinic, space group $C 2 / c, a=13.8197(5), b=24.1188(10), c=$ 19.9231(7) $\AA, \beta=107.468(2)^{\circ}, V=6334.4(4) \AA^{3}, \rho_{\text {calc }}=1.203 \mathrm{~g} \mathrm{~cm}^{-3}, \mu$ 
$=0.578 \mathrm{~mm}^{-1}, \quad \mathrm{Z}=4$, reflections collected: 34159 , independent reflections: $5610 \quad\left(R_{\text {int }}=0.0851\right)$, final $R$ indices $[I>2 \sigma I]: R 1=0.1147$, $w R 2=0.2865, R$ indices (all data) $R 1=0.1544 . w R 2=0.3124$. The methoxy group is disordered over two possible locations (70:30) in the 5 molecule. The modelling of this is somewhat hampered by one of the potential sites being on the edge of a channel which is most likely filled with disordered solvent. This data was collected on a Bruker Nonius KappaCCD with a Mo rotating anode generator; standard data collection and processing procedures were followed.

1. R. K. Afshar, R. Bhalla, J. M. Rowland, M. M. Olmstead and P. K. Mascharak, Inorg. Chim. Acta, 2006, 359, 4105-4113.

2. N. W. Alcock, G. Clarkson, P. B. Glover, G. A. Lawrance, P. Moore and M. Napitupulu, Dalton Trans., 2005, 518-527.

3. S. Hazra, S. Naskar, D. Mishra, S. I. Gorelsky, H. M. Figgie, W. S. Sheldrick and S. K. Chattopadhyay, Dalton Trans., 2007, 4143-4148.

4. A. K. Singh and R. Mukherjee, Inorg. Chim. Acta, 2007, 360, 3456$20 \quad 3461$.

5. F. H. Allen, Acta Cryst. B., 2002, 58, 380-388.

6. K. Kavallieratos, C. M. Bertao and R. H. Crabtree, J. Org. Chem., 1999, 64, 1675-1683.

7. P. A. Gale, J. Garric, M. E. Light, B. A. McNally and B. D. Smith, 25 Chem. Commun., 2007, 1736-1738.

8. S. O. Kang, D. Powell and K. Bowman-James, J. Am. Chem. Soc., 2005, 127, 13478-13479.

9. P. A. Gale, S. E. García-Garrido and J. Garric, Chem. Soc. Rev., 2008, 37, 151-190.

30 10. S.-K. Chang, D. van Engen, E. Fan and A. D. Hamilton, J. Am. Chem. Soc., 1991, 113, 7640-7645.

11. M. G. Fisher, P. A. Gale and M. E. Light, New J. Chem., 2007, 31, 1583-1584.

12. P. A. Gale, S. Camiolo, G. J. Tizzard, C. P. Chapman, M. E. Light, S. J. Coles and M. B. Hursthouse, J. Org. Chem., 2001, 66, 78497853.

13. P. A. Gale, Chem. Commun., 2005, 3761-3772.

14. P. A. Gale, Acc. Chem. Res., 2006, 39, 465-475.

15. S. Camiolo, P. A. Gale, M. B. Hursthouse, M. E. Light and A. J. Shi, Chem. Commun., 2002, 758-759.

16. P. A. Gale, K. Navakhun, S. Camiolo, M. E. Light and M. B. Hursthouse, J. Am. Chem. Soc., 2002, 124, 11228-11229.

17. S. Camiolo, P. A. Gale, M. B. Hursthouse and M. E. Light, Org. Biomol. Chem., 2003, 1, 741-744.

45 18. C. Fruit, A. Turck, N. Pie, L. Mojovic and G. Queguiner, Tetrahedron, 2002, 58, 2743-2753.

19. C. J. Medforth, M. O. Senge, K. M. Smith, L. D. Sparks and J. A. Shelnutt, J. Am. Chem. Soc., 1992, 114, 9859-9869.

20. M. Friedman, J. Org. Chem., 1965, 30, 859-863.

50 21. J. Jurczak and T. Zielinski, Tetrahedron, 2005, 61, 4081-4089.

22. A. N. Dwyer, M. C. Grossel and P. N. Horton, Supramolecular Chem., 2004, 16, 405-410.

23. J. L. Bricks, G. Reck, K. Rurack, B. Schulz and M. Spieles, Supramolecular Chemistry, 2003, 15, 189-197.

55 24. M. Ray, D. Ghosh, Z. Shirin and R. Mukherjee, Inorg. Chem., 1997, 36, 3568-3572.

25. A. K. Patra and R. Mukherjee, Inorg. Chem., 1999, 38, 1388-1393.
26. R. Kapoor, A. Pathak, P. Kapoor and P. Venugopalan, Polyhedron, 2006, 25, 31-38.

60 27. R. Kapoor, A. Kataria, P. Venugopalan, P. Kapoor, G. Hundal and M. Corbella, Eur. J. Inorg. Chem., 2005, 3884-3893.

28. H. J. Kruger and R. H. Holm, J. Am. Chem. Soc., 1990, 112, $2955-$ 2963.

29. E. C. Constable, Tetrahedron, 1992, 48, 10013-10059.

65 30. S. L. Jain, P. Bhattacharyya, H. L. Milton, A. M. Z. Slawin, J. A. Crayston and J. D. Woollins, Dalton Trans., 2004, 862-871.

31. D. S. Marlin, M. M. Olmstead and P. K. Mascharak, Inorg. Chem., 1999, 38, 3258-3260.

32. D. S. Marlin, M. M. Olmstead and P. K. Mascharak, Inorg. Chim. $70 \quad$ Acta, 2001, 323, 1-4

33. J. M. Rowland, M. M. Olmstead and P. K. Mascharak, Inorg. Chem., 2002, 41, 2754-2760.

34. S. R. Zhu, W. W. Brennessel, R. G. Harrison and L. Que, Inorg. Chim. Acta, 2002, 337, 32-38.

75 35. R. J. Cernik, W. Clegg, C. R. A. Catlow, G. Bushnell-Wye, J. V. Flaherty, G. N. Greaves, M. Hamichi, I. Burrows, D. J. Taylor and S. J. Teat, 1997, 4, 279-286.

36. W. J. Clegg, J. Chem. Soc., Dalton Trans., 2000, 3223-3232. 